\title{
A arquitetura da soberania: a atualidade do conceito de decisão em Hans Kelsen e Carl Schmitt
}

\author{
José Augusto Medeiros \\ Mestre em Direito pela Universidade Federal de Santa Catarina (UFSC). Pós-graduado em \\ Direito do Estado pela Universidade Federal do Rio Grande do Sul (UFRGS).
}

\begin{abstract}
Resumo
O presente artigo tem como objetivo apresentar como o conceito de "decisão" é construído nas obras de Hans Kelsen e Carl Schmitt. O trabalho analisa a argumentação de tais autores em obras selecionadas e, a partir daí, procura demonstrar de que modo a construção conceitual de decisão, por meio da ideia de soberania, vincula-se à legitimação do Estado de Exceção. Ao final, o trabalho busca apontar algumas nuanças desse discurso no atual cenário jurídico-político nacional.
\end{abstract}

Palavras-chave

Hans Kelsen; Carl Schmitt; Soberania; Decisão; Estado de Exceção.

\section{Sovereignty's architecture: the present concept of decision in Hans Kelsen and Carl Schmitt}

\begin{abstract}
The following article aims to present how the concept of "decision" is built in Hans Kelsen's and Carl Schmitt's work. The article analyzes the arguments provided by the authors in selected works and, then, looks to demonstrate in which way the current concept of decision, through sovereignty idea, attaches itself to the legitimacy of State of Exception. In the end, the article tries to point out few aspects from this discourse in the current juridical-political national scenario.
\end{abstract}


Keywords

Hans Kelsen; Carl Schmitt; Sovereignty; Decision; State of Exception.

\section{Sumário}

Introdução; 1. A lógica da argumentação. Entre o Estado total e a liberdade do Estado de Direito; 1.1 Carl Schmitt e a teoria da soberania; 1.2 Hans Kelsen e a ordem normativa. A decisão como norma. O princípio da máxima legalidade estatal; Considerações Finais. Estado, direito e Constituição.; Referências Bibliográficas

\section{Introdução: o contexto da argumentação. Encontrando o lugar}

\section{de fala dos autores}

De acordo com Georg Jellinek (2000, p. 361), o Estado se obriga a cumprir o direito que ele mesmo estabelece. Isso se dá por meio do que o autor denomina de "autolimitação" do Estado com o fim de garantia-jurídica. Em outras palavras, a autolimitação permitiria o controle do Estado por sua própria jurisdição, entendida, conforme observa Gilberto Bercovici (2008, p. 216), como fundamental para a formação do constitucionalismo: princípio da máxima legalidade da função estatal (KELSEN, 2003b, p. 239). É assim que o poder do Estado, pela autolimitação, adquiriria o caráter de poder exercido dentro dos limites jurídicos (BERCOVICI, 2008, pp. 216-217).

O pensamento de Jellinek é derivação direta, ou é ele mesmo propulsor, da teoria da autolimitação do Estado. A discussão que norteia esta teoria tem como elemento central a soberania popular: Quem é o soberano? Duguit, ao seu turno, afirmará: se o Estado é soberano, não tem limites; se tem limites, não é soberano (apud $\mathrm{BERCOVICI}$, 2008, p. 208). A teoria da autolimitação corresponde a um contexto socioeconômico que se inicia no final do séc. XIX e ganha força nas primeiras décadas do século XX. Momento em que os grandes Estados se metamorfoseavam para se adaptar à crescente democratização progressiva da sociedade. Gilberto Bercovici (2008) observa que este período teria se caracterizado pela coalizão e criação de instituições com reconhecimento constitucional, as quais previam a participação direta do povo no poder público.

Com a democracia de massas, afirma Bercovici (2008, p. 236), teria surgido a novidade do papel crescente dos partidos políticos, os quais alteraram, com a industrialização e a ampliação do papel do Estado na economia, a configuração estatal. Sobretudo, trata-se de um período marcado por um sistema político que tenta se preservar diante das profundas crises oriundas de mudança culturais e socioeconômicas, em especial, frente às crises que surgiram da complexidade da democracia de massas. 
No campo do direito, conforme aponta Hespanha (2005, p. 429), o individualismo desenfreado que havia servido de base às codificações modernas, nesta época, é posto de parte no ensino do direito positivo. Procura-se subordinar o indivíduo à sociedade e absorver o direito privado no direito social. No âmbito das fontes do Direito, observa Hespanha (2005, p. 432), teria sido introduzida alguma distanciação em relação ao legalismo. Especificamente na Alemanha do início do século XX, a igualdade política e o sufrágio universal geraram um parlamento com maioria de trabalhadores que tendiam ao socialismo, ampliando, assim, a legislação econômica. Fato que culminou com o aumento da disputa do controle do Estado pelas várias forças econômicas.

A Constituição de Weimar reflete muito bem esse contexto. Ela tentou equilibrar os interesses de esferas antagônicas num momento em que a ordem econômica mundial cambaleava. Para Gilberto Bercovici (2003, p. 11), a Constituição de Weimar foi elaborada sem maiorias claras, num contexto político cujo equilíbrio era precário e instável.

Ao mesmo tempo em que a Constituição de Weimar representou um compromisso politicamente aberto de renovação democrática, ela foi gradativamente responsabilizada pela crise econômica que se acentuava. Era comum a alegação de que o Estado Alemão não tinha margem econômica para suportar os compromissos sociais assumidos pela Constituição. Por conseguinte, observa Bercovici (2008), a questão da legitimidade política (de representação) também é agravada na medida em que o sufrágio universal atribui aos trabalhadores posição decisiva na condução do Estado.

A partir do final da década de 1920, os setores economicamente fortes deliberadamente iniciam uma ofensiva campanha de combate aos direitos e garantias sociais previstos na Constituição de Weimar (BERCOVICI, 2011). A propagada destruição da Constituição republicana e do Estado Social passa a ser vista como necessária para o retorno do crescimento econômico. Por outro lado, instaura-se um questionamento direto à legitimidade da Constituição. Paralelamente a isso, após 1929, com o agravamento da crise econômica, a reação dos setores dominantes se volta também contra os direitos e do Estado Social previstos na Constituição (BERCOVICI, 2003).

O compromisso da Constituição de Weimar, aponta Bercovici (2003), é percebido como frágil. Para os juristas da social-democracia, as forças motrizes do capitalismo organizado seriam as mesmas que ameaçavam o equilíbrio político-constitucional e a forma democrática parlamentar. O parlamento, já composto por uma pluralidade de representação, segundo Bercovici (2008), teria sido acusado de promover a inflação e o desequilíbrio fiscal, com a denúncia dos gastos sociais como causadores da crise econômica. 
Frente a tal contexto, a resposta encontrada pelos juristas da social-democracia foi a de reverter o processo de perda de centralidade do Parlamento, atacando, especificamente, dois pontos: i) o crescimento do poder burocrático; e ii) o deslocamento de funções do Legislativo para o Judiciário (BERCOVICl, 2008). Este último - muito conhecido dos brasileiros na atualidade - configura-se como ponto nuclear da discussão doutrinária da época.

$\mathrm{Na}$ tentativa de contornar a crise delineada, o poder jurisdicional passa a ser visto (e se ver) como uma autoridade decisória autônoma. O Judiciário busca se desvincular da lei - produzida e votada pelo Parlamento - tendo como pressuposto basilar que o direito positivo é um obstáculo à sua atividade. Para tanto, ele lança mão de teorias de interpretação e de hermenêutica do sistema, tencionando, inclusive, o controle judicial dos atos do Parlamento ou do controle judicial das leis (BERCOVICI, 2011).

É neste quadro contextual que é possível encontrar o lugar de fala dos dois autores abordados neste trabalho. Eles estão situados no contexto de compreensão e conformação das relações do Estado e da legitimidade da Constituição, núcleo essencial das preocupações do período. Cada um, ao seu modo, busca soluções para a crise representativa diagnosticada. Suas teorias são construídas sob a perspectiva de perceber os limites do Estado, cuja diagnose está submersa no problema da atribuição da soberania. Com efeito, o conceito de "decisão" para tais autores, revela-se como fio condutor para o preenchimento conceitual do termo "soberania".

No horizonte do direito constitucional, Hans Kelsen se lança em defesa da liberdade sob o primado do Parlamento e dos partidos políticos, haja vista que concebe como principal função do Estado a função legislativa (KELSEN, 2000, p. 253). A soberania, para o autor, seria a pressuposição de uma ordem normativa, cuja validade não é dedutível de qualquer ordem superior (KELSEN, 2003, p. 372). Neste aspecto, a “decisão", em Kelsen, será dotada de natureza normativa.

De outro lado, Carl Schmitt busca soluções no fortalecimento do Executivo. As obras analisadas de Schmitt indicam que o autor parte do pressuposto de que a crise que assolou a sociedade europeia teria exclusivamente ocorrido pela ampliação da democracia. Para Schmitt, observa Bercovici (2008, p. 236), a soberania popular era um perigo que precisava ser afastado a qualquer preço para se construir uma cidade "bem governada". Na concepção schmittiana, a questão da soberania é respondida pela análise da realidade natural, na qual se toma o máximo poder real daquele que decide a situação excepcional. Para Schmitt, a "decisão" não se vincularia à lei, ao contrário, ela se realizaria quando a ordem normativa estivesse suspensa. 
A narrativa doutrinária sobre a soberania protagoniza este momento. É a estruturação de tal conceito que delineia o discurso dos autores analisados, bem como estrutura a legitimidade para que cada um, ao seu modo, defenda a forma pela qual o Estado pode ser limitado e, principalmente, para que se possa responder a questão de quem detém a competência de limitá-lo.

Considerando a hipótese dos limites estarem formalmente postos na Constituição, o debate dos autores consequentemente seguirá para a defesa de quem é o detentor da guarda da Constituição. Em outras palavras, é por meio da formatação do conceito de decisão que, em última análise, é possível indicar quem é o soberano.

\section{A lógica da argumentação. Entre o Estado total e a liberdade} do Estado de Direito

\subsection{Carl Schmitt e a teoria da soberania}

O trabalho de Schmitt na obra Teologia Política tem como pedra angular a ideia de soberania. É por meio da análise da noção conceitual de soberania que o autor propõe uma reflexão acerca dos limites de atuação do Estado, sua legitimidade e, não menos importante, sobre os poderes do chefe de Estado, segundo Schmitt, o soberano. Para o autor (2006, p. 87), "soberano é quem decide sobre a situação execepcional". Com efeito, o conceito de decisão, em Schmitt, pode ser lido como subproduto da definição que o autor imputa à significação da ideia de soberania.

A concepção schmittiana do conceito de soberania está ancorada no que ele denomina de situação especial, para ele definida como o Estado de Exceção. Para Schmitt (2006, p. 88) o caso excepcional é o caso não circunscrito na ordem jurídica vigente. Ele pode ser definido, no máximo, como caso de emergência extrema ou, ainda, de perigo à existência do Estado. No entanto, não pode estar circunscrito ou limitado numa tipificação jurídica. Segundo Schmitt (2006, pp. 88-89), é "somente no contexto do Estado de exceção que se torna atual a questão do sujeito da soberania".

De igual modo, é somente o Estado de Exceção que permite a verificação de tal problemática. O conceito de decisão em Schmitt é percebido de melhor maneira no Estado de Exceção, haja vista que, segundo o autor, "o normal não provaria nada", conquanto que "a exceção provaria tudo" (SCHMITT, 2006, p. 94). A exceção não só confirmaria a regra, mas a própria regra somente viveria na exceção. Segundo Schmitt (2006), o caso da exceção revelaria com maior clareza a existência da autoridade estatal. 
Nesse quadro teórico, a ideia de soberania revela-se como o núcleo de discussão entre o direito e a política, num cenário exclusivamente preenchido pela exceção à normalidade. Para justificar seu pensamento, Schmitt (2006, p. 107) invoca a fórmula de Hobbes, para quem "a autoriade, não a verdade, faria a lei" ("auctoritas, non veritas, facit legem"). Tem espaço nessa construção teórica, ainda, o pensamento dos filósofos da restauração, dentre os quais, princilamente, Joseph De Maistre, Louis-Gabriel-Ambroise, o Visconde Bonald, e Juan Donoso Cortés.

É, entretanto, com o pensamento de Jean Bodin que a teoria de Schmitt guarda maior relação. Bodin é o grande teórico do Estado. Para o Jurista Francês, a soberania teria surgido como um poder preeminente, ou seja, um poder que não reconhece superior. Na definição de Bodin, a soberania é vista como o poder supremo sobre os cidadãos e os súditos. Para Fábio Konder Comparato (1985, pp. 86-87), em Bodin, o poder supremo dos cidadãos seria um poder desvinculado das leis e, portanto, livre dos comandos de qualquer outra pessoa.

Vale lembrar, no entanto, que a teoria de Jean Bodin é filha legítima do seu próprio tempo. Em linhas gerais, em que pese ter representado o instrumento doutrinal de independência do monarca, por outro lado, conforme observa Airton Seelaender (2006, p. 200), a teoria de Bodin, também ao modo do seu tempo, "teria estabelecido alguns limites ao poder". Para Seelaender (2006, p. 200), embora Bodin tendesse a situar entre tais leis só as concernentes à sucessão da Coroa, à inalienabilidade da soberania e do patrimônio real e à contenção do poder papal na igreja francesa, o fato é que seus escritos revelariam, também, dentro do próprio direito humano positivo, a busca de alguns limites do poder. De uma maneira geral, é possível afirmar que o objetivo principal deste teórico é buscar uma solução para fortalecer o poder real, de modo que a resposta para tanto é encontrada na "souverinité".

José Adelino Maltez ${ }^{1}$ ressalta que Carl Schmitt chama a atenção para o fato de que Bodin, no cap. X, do Livro Da República, introduz o o conceito de decisão no coração da noção de soberania, quando considera que o príncipe deixa de estar vinculado à promessa que fez às instâncias inferiores se a necessidade é urgente. Fábio Konder Comparato (1985, p. 86-87) adverte que, na concepção de Bodin, a soberania não se apresentaria apenas como um poder acima dos outros, mas, também, como "fonte geradora de todos os demais poderes".

1 Verbete do Dicionário do Centro de Estudos do Pensamento Político do Instituto Superior de Ciências Sociais e Políticas da Universidade de Lisboa (ISCSP). Disponível em:<http://www.iscsp.ulisboa.pt/ cepp/indexfro1.php3?http://www.iscsp.ulisboa.pt/ cepp/concei tos_politicos/soberania.htm >. Acessado em fevereiro de 2015. 
Para Schmitt (2006), é neste lugar que residiria o ponto central da Teoria do Estado e o verdadeiro conceito de soberania, a partir do qual se pode, na visão do autor, extrair a chave para entender a formulação do conceito de decisão. Segundo Schmitt (2006, p. 88), o decisivo, nas declarações de Bodin, é que o autor francês traduz a explicação das relações entre o príncipe e as corporações a um simples "é isso ou aquilo" por meio de sua remessa ao "caso de emergência".

Na visão de Schmitt (2006, p. 89), esse seria, na verdade, o fator mais marcante da definição de soberania para Bodin, o qual a considera uma "unidade indivisível e decide definitivamente a questão do poder do Estado". Citando De Maistre, Schmitt (2006, p. 122) destaca que "a soberania significa decisão e o valor do Estado consiste em apresentar uma decisão".

A partir desta constatação, Schmitt (2006) adverte que a ideia de soberania revelase como ponto culminante do poder e não de desvio do poder. Nessa linha de argumentação, Schmitt (2006) afirma que não seria o conceito de soberania que gera discussões, mas, sim, sua aplicação concreta, no sentido de saber quem toma as decisões em caso de conflito ou de saber no que se constitui o interesse público ou estatal, a segurança e a ordem pública - le salut public.

Em Schmitt, conforme observa Alexandre Franco de Sá (2004), a decisão que ocorre no Estado de Exceção, ou seja, a decisão que se torna independente da norma ou da ordem jurídica e a suspende em nome da ordem, evocaria um poder que surge normativamente desvinculado e que é, desse modo, um poder supremo ou soberano. Em outras palavras, a decisão do soberano, por sua própria natureza, seria a expressão de um poder desvinculado do ordenamento legal.

Seguindo esta lógica, a decisão se distinguiria da norma jurídica. Para Schmitt (2006, p. 91), a decisão seria formulada paradoxalmente e a autoridade, com isso, comprovaria que, "para criar justiça, ela não precisa ter justiça". Aqui, Schmitt (2006, pp. 92-93), mais uma vez, socorre-se na exceção que, segundo ele, seria "o que não se pode acrescentar". A exceção seria subtraída da Constituição geral e, ao mesmo tempo, revelaria em sua pureza absoluta um elemento formal jurídico mais específico, que seria, ao final, a decisão.

Assim, a decisão, para Schmitt, como produto ou ela mesma elemento formal do Estado de Exceção, tem caráter extranormativo. A decisão, segundo o autor (2006, p. 92), não se originaria da norma ou de um sistema racional; ela surgiria "do nada". O autor observa que nas afirmações de De Maistre já havia uma redução do Estado ao momento da decisão. É esta decisão que, na visão de Schmitt (2006, p. 130), seria uma "decisão absolutamente pura, não pensada e não justificada". Com alguma divergência sobre tal 
informação - mas ainda norteado por ela -, em outro trecho, Schmitt (2006, p. 106) conclui que "encarada normativamente, a decisão nasceu do nada; sua força jurídica é algo diverso da motivação".

Parece ser justamente neste campo do decisionismo que o discurso de Schmitt se aproxima com mais eloquência da argumentação hobbesiana². Alexandre Franco de Sá (2004, p. 412) observa que os elementos decisionistas do direito restam expressos na teoria de Schmitt, na medida em que o autor alemão considera o direito como uma realidade composta entre dois fatores irredutíveis, a saber: i) "o elemento da norma jurídica, o direito na sua pureza"; e ii) "o elemento da realização da norma, vista como a concretização do direito na própria realidade".

Para Schmitt (2006), se uma norma jurídica, enquanto entidade normativa, não se realiza por si só, ela só pode ser realizada a partir de uma decisão que, nessa medida, não pode ser determinada por aquela norma, mas pela realidade. Neste aspecto, Schmitt (2006 pp. 104-105) observa que "cada ordem se baseia numa decisão", e o conceito de ordem jurídica, aplicado como algo natural, também “contém em si mesmo a oposição de dois diferentes elementos do jurídico". De acordo com a teoria schmittiana, até mesmo a ordem jurídica, como toda a ordem, estaria fundamentada numa decisão, e não numa norma.

Se a soberania é o ponto culminante do poder, a existência do Estado (de Exceção), em Schmitt, acaba atingindo uma indubitável superioridade sobre a validade da norma jurídica. É assim que a decisão, para Schmitt (2006), liberta-se de qualquer ligação normativa e torna-se, num certo sentido, absoluta. Consequentemente, a autoridade prova que, para criar justiça, ela não precisa de justiça. A decisão, neste instante, dentro da teoria esboçada por Schmitt, torna-se independente da fundamentação argumentativa e passa a ter um valor autônomo.

Segundo Schmitt (2007), seria preciso implantar uma ordem concreta do Estado, e não uma ordem abstrata, fundada no factual. Para o autor (2007, p. 52), uma norma genérica, como se apresenta a norma jurídica válida, "não pode nunca assimilar uma exceção absoluta" e, portanto, nunca justificar totalmente a decisão tomada em um verdadeiro caso de exceção.

\footnotetext{
${ }^{2}$ Bercovici (2011, p. 58) salienta que a concepção do Estado de Schmitt é hobbesiana, não é dialética. Para Bercovici (2011), o Estado moderno, segundo Schmitt, teria nascido historicamente de uma técnica política. E o efeito inovador da filosofia política de Hobbes foi o de ter concebido o Estado como uma grande máquina, ligado à revolução técnico-industrial. Com efeito, o Estado em Schmitt, observa Bercovici (2011, p. 58), seria obra do homem e se distinguiria de todas as formas anteriores de unidade política.
} 
Ao analisar a posição que o chefe de Estado desempenha, Schmitt (2007) observa que o presidente do Reich encontra-se no centro de todo um sistema de neutralidade e independência político-partidária, que teria sido construído sob uma base plebiscitária. Para o autor (2007), o ordenamento do Reich alemão dependia do Presidente na mesma medida em que as tendências do sistema pluralista dificultavam, ou até mesmo impossibilitavam, o funcionamento normal do Estado legiferante. Segundo Gilberto Bercovici (2003, p.63), para Schmitt, o parlamentarismo liberal era antipolítico, de modo que, para o autor alemão, a "fé no parlamentarismo liberal seria própria do liberalismo e não da democracia". O característico da democracia seria a homogeneidade.

É importante observar que a fala de Schmitt está posicionada (e inserida) num contexto em que a soberania já havia sofrido desvios semânticos. A respeito do assunto, Fábio Konder Comparato (1985) observa que a concepção original de soberania, extraída dos autores legistas reais do século XVI, sofreu dois desvios semânticos na sua transferência para o povo. O primeiro desvio diz respeito à transferência de soberania, até então aplicada a apenas um indivíduo, para o povo com entidade coletiva; conquanto que o segundo desvio semântico, na visão de Comparato (1985), seria representado pela institucionalização do poder representativo, por meio da qual, aparece um singular soberano, que aceita submeter-se ao governo de outrem.

Em que pese tais desvios, por meio da linha de argumentação apresentada em suas obras, Schmitt parece (re)criar uma lógica de legitimidade para o poder de decisão do Führer que, na sua concepção, manifestaria o poder soberano. Com efeito, a saída que Schmitt encontrou para a aludida crise, que teria sido provocada pela Constituição de Weimar, tem correspondência com um discurso detalhadamente orquestrado para atingir em cheio o sistema político-partidário, intitulado como grande vilão da crise econômica da Alemanha daquela época. Como em Bodin, na hipótese do sistema pluralista dificultar o funcionamento do Estado, o Führer deixa de estar vinculado à sua base legitimadora, haja vista que a necessidade é urgente. Aqui, o ponto a ser atacado não poderia ser outro senão a soberania.

É importante evidenciar que ao insistir no caráter essencialmente indivisível da soberania, tanto Bodin como os demais legistas reais do século XVI tinham em mente a vontade do monarca, que, a não ser em caso de "esquizofrenia aguda, não podia, ao mesmo tempo, querer e não querer" (COMPARATO, 1985, pp. 88-92). Esta informação torna-se relevante para identificar o quão fora de lugar pode parecer a teoria de Schmitt quando tenta legitimar, em plena democracia, o caráter indivisível da soberania. Nesse sentido, Gilberto Bercovici (2003) sugere ser importante perceber que Schmitt, bem como seus discípulos, como Ernst Fortshoff, advertia sobre uma nova representação da 
estatalidade que possibilitasse o surgimento de uma autoridade estatal verdadeira, ao contrário de Weimar.

$\mathrm{Na}$ escala deste discurso legitimador do poder do Führer - ou da soberania no Estado de Exceção -, por meio do Führerprinzip, Schmitt (2006) prega a suspensão da lei. O autor de Teologia Política argumenta que (do Estado de Exceção) faz parte uma autorização em princípio ilimitada, a significar a suspensão de toda a ordem existente. Por corolário lógico, quando o Estado de Exceção surge, o direito se retira. Em outras palavras, o direito em vigor deixa de ser aplicado para que o soberano surja. Decorre daí uma separação entre ordem e ordem jurídica que, no fundo, representa o peculiar desequilíbrio que há no Estado de Exceção entre direito público e fato político.

É assim que, na teoria de Schmitt (2006, 2007), o Estado encontra limites no soberano e, este, por sua vez, como soberano, não teria limites, haja vista que legitimado e contextualizado na suspensão de toda a ordem (jurídica-normativa) vigente. Em decorrência disso, a decisão toma contornos autoritários ilimitados, correspondendo, na sua natureza, ao desprendimento total do Estado de Direito.

\subsection{Hans Kelsen e a ordem normativa. A decisão como norma.}

\section{princípio da máxima legalidade estatal}

Ao contrário de um conceito de decisão afastado da legalidade, o processo de teorização da ideia de decisão, trabalhado por Hans Kelsen, segue o compasso da sua teoria do direito, na qual a ordem normativa alcança o centro do discurso. Em vista da importância que o direito assume, a teoria kelseniana é apresentada a partir de uma metodologia kantiana e tem como finalidade a construção de um sistema de conhecimento puro, livre de interferência exógena.

Como visto, em Schmitt, o direito até então existente não seria mais apropriado para as novas estruturas sociais (BERCOVICl, 2008), e reclamaria, assim, por uma nova remodelagem, na qual o Estado Total poderia apresentar medidas concretas para conter a crise. Ao que tudo indica, Kelsen, à sua maneira, também identifica que o direito existente estaria comprometido. Tal percepção leva-o a compreender a necessidade do direito ser (re)visto por sua natureza científica.

Por conseguinte, há para Kelsen dois conceitos de Estado: o conceito sociológico, não-científico, e o conceito jurídico, visto pelo autor como científico. A despeito dessa interpretação, os limites do Estado se circunscreviriam num conceito de soberania exclusivamente jurídico e essencialmente fundamentado na norma suprema do 
ordenamento jurídico. Na perspectiva kelseniana, a limitação do Estado estaria adstrita à sua ordem jurídico-normativa, ou seja, científica. Kelsen (2003, p. 372) expressa a ideia de que a "soberania seria a ordem jurídica do próprio Estado". A figura do Estado, por sua vez, segundo Kelsen (2003), estaria subordinada à sua própria ordem normativa, a qual, por sua vez, se submeteria à norma suprema.

Se Schmitt (2006) lança mão do paradigma da exceção para construir o conceito de soberania e, consequentemente, de decisão, Kelsen procura fazer sua construção argumentativa do sistema jurídico a partir da forma por meio da qual a norma opera. Para Kelsen (2003, p. 4), “a norma representaria o sentido do ato através do qual uma conduta é prescrita, permitida ou, especialmente, facultada", no sentido de adjudicada à competência de alguém. Na teoria kelseniana, a norma é percebida como um "dever-ser" e o ato de vontade de que ela constitui o sentido é um "ser".

Nesta linha de distinção, Kelsen $(2003$, p. 41) sugere que "o direito é uma ordem de coerção" e, como ordem de coerção - conforme o grau de evolução -, revela-se como "ordem de segurança que tem contornos de uma ordem de paz". A perspectiva de uma ordem de paz, ao seu turno, cuida de uma lógica que guarda íntima relação com o postulado kantiano de lei universal ${ }^{3}$. A norma suprema consignada por Kelsen tem influência expressa na lei universal de Kant (2008), para quem qualquer ação revela-se justa desde que seja capaz de coexistir com a liberdade de todos de acordo com uma lei universal.

Segundo Kelsen (2003, p. 259), a Constituição representaria a "fonte das normas gerais produzidas por via legislativa ou consuetudinária". No mesmo sentido, a norma geral constituiria-se como fonte da "decisão" que "aplica e é representada por uma norma individual". Para o autor (2003, p. 259) uma "norma somente pertence a uma ordem jurídica porque é estabelecida de conformidade com uma outra norma desta mesma ordem jurídica". Frente a esse quadro, o conceito de decisão, em Kelsen (2003, p. 263), pode ser visto como expressão direta da norma fundamental. Na teoria kelseniana, a decisão não se sujeita, portanto, à legitimação pelo silêncio da lei ou por mera construção doutrinária.

Em última análise, a teoria normativa de Kelsen leva ao pressuposto de que uma norma jurídica é pertencente a uma determinada ordem jurídica na medida em que ela é criada por um órgão da respectiva comunidade. É dizer, a norma jurídica pertence a uma

${ }^{3}$ De acordo com o imperativo kantiano, o postulado da Lei Universal é enunciado pela máxima: "age externamente de tal maneira que o uso livre do teu arbitrio possa coexistir com a liberdade de todos segundo a lei universal". Para Kant, "qualquer ação é justa se for capaz de coexistir com a liberdade de todos de acordo com a lei universal, ou se na sua máxima a liberdade de escolha de cada um puder coexistir com a liberdade de todos de acordo com a lei universal" (2008, p. 77). 
determinada ordem jurídica se foi criada pela comunidade que, portanto, detém a soberania.

Parece ser justamente dentro desse esquema de dedução que Kelsen encontra subsídios para refutar a tese de Carl Schmitt. Para Kelsen (2003), seria desacertado distinguir entre atos de criação e atos de aplicação do direito. Segundo a argumentação do autor austríaco, se os casos-limite forem deixados de lado - a pressuposição da norma fundamental e a execução do ato coercitivo -, entre os quais se desenvolve o processo jurídico, "todo ato jurídico acaba sendo visto como, simultaneamente, aplicação de uma norma superior e produção de norma inferior, regulada pela norma superior" (KELSEN, 2003, p. 261).

A decisão, vista como norma, portanto, somente alcança tal condição porque representa, em última instância, a aplicação de uma norma superior. A proposição kelseniana, deste ponto de vista, não se distancia, como em Schmitt (2006), da ordem normativa vigente, nem mesmo quando hipoteticamente é percebida no Estado de Exceção. Ao contrário, ela cuida de reafirmar a vigência da sua força normativa visto que, ao mesmo tempo, ratifica e (re)produz uma norma inferior.

Esta perspectiva é melhor identificada quando Kelsen (2003) sugere que, por aplicação da Constituição, operar-se-ia a criação das normas jurídicas gerais através da legislação e do costume; e, na aplicação destas normas gerais, realizar-se-ia a criação das normas individuais por meio das decisões judiciais e das resoluções administrativas.

A decisão passa a ser vista como "criação de uma norma inferior com base numa norma superior" ou, ainda, como "execução do ato coercitivo estatuido por uma norma" (KELSEN, 2003, p. 261). Kelsen (2003, p. 261) observa, ainda, que "todo ato criador de direito deve ser um ato aplicador do direito". Para poder valer como ato da comunidade jurídica, o ato criador deve ser a aplicação de uma norma jurídica preexistente ao ato. Por esse motivo, a criação jurídica deve, na visão kelseniana, ser concebida como aplicação do direito.

Em outras palavras, segundo Kelsen (2003), para poder valer como ato da comunidade jurídica, a aplicação de uma norma - a decisão, portanto - deve representar a aplicação subsuntiva de uma norma jurídica preexistente ao ato (de decisão). Tomandose como verdadeira tal construção, a decisão estaria sempre vinculada à norma e, só nesta condição, alcançaria validade como ato da comunidade jurídica. Neste sentido, a decisão é tão somente a continuação do processo de criação jurídico-normativa, de modo que a função do tribunal é criadora de direito ou, em outras palavras, criadora de uma norma jurídica. 
Consequentemente, a decisão judicial representaria, em seu fundamento, uma norma jurídica individual extraída do escalonamento do sistema normativo. Sua legitimidade, então, não estaria adstrita a quem detém o poder. O homem não se submeteria à soberania exercida por outro homem, mas à soberania representada pela lei, que, em última análise, é quem legitima o representante da soberania.

Imerso nesse contexto teórico, Kelsen (2003) observa que, do ponto de vista de uma consideração centrada sobre a dinâmica do direito, o estabelecimento da norma individual pelo tribunal representaria um estádio intermediário do processo que começa com a elaboração da Constituição e segue, através da legislação e do costume, até a decisão judicial e desta até a execução da sanção. Aludido processo, no qual o direito se recriaria em cada momento, parte do geral (ou do abstrato) para o individual (ou concreto). Seria um processo de individualização ou concretização sempre crescente.

Norberto Bobbio (1986) destaca que a concepção dinâmica do ordenamento jurídico de Kelsen pode ser traduzido na máxima de que o soberano faz a lei apenas se exerce o poder com base numa norma do ordenamento e, somente neste caso, o soberano é visto como legítimo. Especificamente na obra "Jurisdição Constitucional", Kelsen (2003b, p. 42) argumenta que "apenas uma ordem em conformidade com a lei pode pretender obediência, pois apenas ela é uma ordem jurídica legítima".

Ao conceber o ordenamento jurídico como cadeia de normas que criam poderes e de poderes que criam normas, a teoria kelseniana indica ter presente que o marco inicial não é representado pelo poder dos poderes, mas pela norma das normas, a Grundnorm. Todo o direito, assim, emanaria do poder estatal porque o poder estatal seria, em si mesmo, limitado pela lei.

Ao que tudo indica, este ponto é trabalhado por Kelsen como uma contraargumentação às bases bibliográficas e argumentativas de Schmitt. O conceito de soberania utilizado por Schmitt deita suas bases na teoria de Bodin. O conceito de soberania de Bodin, como já dito, está centrado na localização política do soberano. Assim, a soberania, em Bodin, segundo observa Comparato (1985), seria um poder supremo e ilimitado sobre os cidadãos. Não seria, portanto, apenas um poder tecido acima dos outros, mas a fonte geradora de todos os demais poderes.

A tese apresentada por Kelsen, entretanto, parece atacar justamente esta visão de soberania, ou melhor, a visão de soberania que é criada a partir desse pressuposto. A argumentação de Kelsen identifica que apenas uma ordem em conformidade com a lei pode pretender obediência. A grosso modo, isso significa dizer que apenas um poder exercido conforme à lei poderia pretender ser soberano. Aparentemente, Kelsen refuta qualquer possibilidade de um poder soberano ser exercido em desacordo com a lei ou, em 
outras palavras, encontrar legitimidade no poder considerado em si mesmo, como acontece na exceção de Schmitt a partir da ideia embrionária de Bodin.

Para Kelsen (2003, p. 283), "todo o ato jurídico é simultaneamente aplicação de uma norma superior e produção de uma forma inferior que é regulada por aquela norma". A decisão, por conseguinte, revela-se como aplicação do direito na sua perspectiva jurisdicional, haja vista nada mais ser do que a criação de uma norma inferior com base numa norma superior ou, ainda, execução do ato coercitivo por uma norma. A leitura kelseniana observa que todo o ato criador do direito deve ser um ato aplicador de direito, de modo que o ato criador deve refletir a aplicação de uma norma jurídica preexistente ao ato, para poder valer como ato da comunidade jurídica.

A partir desta perspectiva, tem-se que a decisão (e somente ela) é dotada de capacidade para estabelecer uma uma norma jurídica individual, que ganha espaço, também, por meio de uma relação de validade e eficácia. É em consequência disso que a função da norma geral pode consistir em determinar o conteúdo da norma individual produzida através da decisão.

Decorre daí que o conceito de decisão em Kelsen (2003, 2003b) está intimamente ligado à dinâmica do direito presente na sua teoria, ou melhor, diz respeito ao modo pelo qual ele percebe o sistema jurídico - de como a opera a norma. Com efeito, uma decisão judicial não pode, enquanto for válida, ser contrária ao direito. Consequentemente, não se pode falar em conflito entre a norma individual criada por decisão judicial e a norma geral, aplicada pelo Tribunal e criada por via legislativa ou consuetudinária. Para Kelsen (2003b, p. 239), portanto, a "decisão tem sua origem somente na legislação, constituindo-se com uma função estatal e ao mesmo tempo política". Aqui tem lugar, mais uma vez, o princípio da máxima legalidade estatal.

Ao final, em Kelsen (2003), a decisão judicial figura tão somente como a continuação do processo de criação jurídica, de modo que a função do tribunal é criadora de direito a partir do texto. Como consequência, a "decisão judicial é um ato de vontade que faz política" (KELSEN, 2003b, p. 282). O direito, nessa lógica, é visto como imputação da legalidade. $O$ direito é quem cria o direito.

Deste modo, uma autoridade superior que imponha soberania - ou que pretenda exercer poder sob seu nome - somente é compreensível nos termos da normatividade, haja vista que a própria soberania é ordem normativa. Os cidadãos, titulares constitucionais da soberania, estão sujeitos apenas à norma. Nunca a outros homens, monarca ou qualquer sistema exógeno ao produzido pelo ordenamento jurídico. A despeito deste quadro, a purificação que Kelsen destina ao direito em sua teoria atinge, também, o conceito de soberania que, para o autor, apresenta-se como um conceito 
purificado que não encontra (limite em) outra ordem que não seja jurídica ou tampouco pode ser suspenso.

\section{Considerações finaiis. Estado, direito e Constituição.}

O lugar de fala dos autores abordados neste trabalho indica um contexto em que houve uma acentuada dissociação entre a ordem oficial e a ordem real dos poderes legitimados. Conforme exposto nas linhas introdutórias da análise aqui proposta, as primeiras décadas do século XX foram marcadas pela metamorfose da figura de Estado. O sentido de contenção dos balanços políticos e econômicos que endossavam, em alguma medida, no Estado Social, o poder decisório para as mãos do povo foi constantemente revisitado. A Constituição de Weimar figura como exemplo paradigmático deste quadro contextual.

Kelsen e Schmitt, por meio de suas respectivas percepções sobre o papel do direito e o conceito de decisão, desenvolvem com eloquência ímpar a identificação da soberania na realidade de Weimar. O campo limite que se apresenta em Weimar propicia que ambas as teorias desenhem o conceito de soberania demonstrando como a decisão opera dentro desse processo.

A releitura que Schmitt apresenta está umbilicalmente ligada às teses dos autores legistas reais do século XVI. Tal característica é expressa nos trabalhos analisados e serve, como visto, de forte embasamento teórico para dar autoridade aos argumentos neles expostos. Os antagonismos sociais provocados pela Constituição de Weimar, na visão de Schmitt, poderiam ser resolvidos pelo ordenamento concreto e pela revitalização da ideia de direito, a ser empreendido pelas medidas individuais - destinadas a cada grupo - pelo soberano, no caso, o Führer.

Kelsen, por sua vez, embebido em Kant e Georg Jellinek, compreende a necessidade de excluir qualquer possibilidade da ordem jurídica ser infiltrada por forças exógenas, sob o pretexto do perene risco da soberania sofrer um retrocesso e ser encorporada pelo poder em si mesmo. O debate entre os autores analisados e suas contraposições, no entanto, parece não se encerrar no recorte aqui proposto. Weimar é, ainda, atual.

O ambiente jurídico contemporâneo sinaliza por vários ângulos um certo declínio ou transposição do conceito e da ideia de soberania. Há registros claros de contradições e ataques à Constituição sob o argumento de que seu esquema normativo já não corresponderia à realidade efetiva do poder na sociedade. Disso decorre que, tanto no âmbito legislativo quanto no âmbito jurisdicional, em especial no controle de 
constitucionalidade, a força normativa da Constituição cede espaço para rupturas casuísticas das regras constitucionais.

O controle de constitucionalidade ainda é assunto espinhoso no cenário jurídicodoutrinário brasileiro. O tema - relativamente pouco estudado a partir de abordagens densas - revela-se como ponto chave da manutenção e materialização do projeto constitucional. O Brasil adota dois modelos de controle, o abstrato e o concentrado. Enquanto este é típico de alguns países europeus, aquele - ainda que recheado de particularidades - revela-se como representação do modelo norte-americano (BENVINDO, 2014). Em que pese tais influências, Juliano Zaiden Benvindo (2014) observa que as décadas seguintes à Constituição de 1988 foram marcadas por um processo de esvaziamento do controle difuso e de ampliação do controle concentrado.

De todo modo, no sistema brasileiro, o controle de constitucionalidade é pensado a partir da função de contribuir para a consolidação do movimento democrático expresso na CRFB de 1988. É instrumento por meio do qual, em tese, procura-se proteger a Constituição. De acordo com o ordenamento jurídico nacional (art. 102 da CRFB de 1988) este papel (de guarda) compete precipuamente ao Supremo Tribunal Federal. Cumpre a ele proteger a Constituição dos demais poderes.

O problema está, no entanto, como sugere Gilberto Bercovici (2003b), quando o Tribunal Constitucional (ou quem quer que ocupe o papel de instituição guardiã) não se limita mais a defender ou a interpretar a Constituição como instância máxima. Mas, ao contrário disso, passa a se assenhorear dela para a legitimação de fins estranhos ao seu texto. Isso ocorre, sobremodo, por meio do uso de técnicas interpretativas. Em casos como tais, não raras vezes, a Constituição é posta em suspensão e quem decide, decide à sua revelia. Nestas hipóteses, volta-se a velha pergunta: "Quem deve ser o guardião da Constituição?".

O tema pode, ainda, ser expandido. O conceito de decisão, hoje, na esfera da soberania, cuida de um conceito cujo esvaziamento teórico reverbera em todos os outros estratos, não se limitando ao nível de controle de constitucionalidade pelo STF. A título de ilustração, dois casos concretos podem ser pontuados. O primeiro deles trata de decisão judicial em sede recursal, proferida no âmbido do Superior Tribunal de Justiça ${ }^{4}$. Na referida decisão, os Ministros do STJ, em suas razões recursais, supenderam a lei e, com isso, suprimiram um direito garantido por força constitucional.

\footnotetext{
${ }^{4}$ Disponível em:

https://ww2.stj.jus.br/processo/pesquisa/?tipoPesquisa=tipoPesquisaNumeroRegistro\&termo=2014

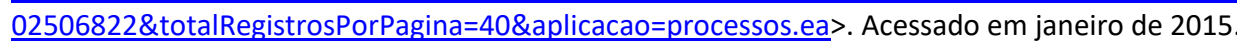


No caso, o Recorrente teve seu recurso negado sob o fundamento de que as custas recursais não haviam sido recolhidas. O Recorrente, no entanto, era beneficiário da justiça gratuita. Mesmo assim, o Ministro relator entendeu que, em que pese o benefício ter sido concedido em primeiro grau, o Recorrente, na oportunidade de interposição do recurso, deveria ter pedido a extensão da benesse para a instância recursal.

Sabe-se, entretanto, que a Lei de Assistência Judiciária, respaldada no direito fundamental do acesso à justiça (art. 5o, LXXIV e XXXV), é clara ao prever que "os beneficiários da assistência judiciária compreendem todos os atos do processo até decisão final do litígio, em todas as suas instâncias". No mais, a referida lei lança mão de outro mecanismo hábil para, se for o caso, provocar a revogação do benefício: "a parte contrária poderá, em qualquer fase da lide requerer a revogação dos benefícios da assistência, desde que prove a inexistência ou o desaparecimento dos requisitos essenciais à sua concessão".

É necessário notar que a revogação não depende exclusivamente da provocação da parte adversa, na medida em que cuida, também, de prerrogativa do magistrado, o qual pode, de ofício, revogar o benefício (como, igualmente, não concedê-lo, se for o caso). Isto significa que existem outros instrumentos - que não o de supressão de um direito fundamental - para que tal questão seja (re)vista.

Exigir da parte que, sem fundamento legal algum, "renove" o pedido, quando a lei é expressa em observar que os benefícios compreendem todos os atos até a instância final é, no mínimo, intrigante. Em uma análise mais detida, pode-se afirmar que a decisão é equivocada e perigosa. Demonstra, pois, a incapacidade cada vez maior do Poder Judiciário observar a lei, propagando um decisionismo raso e flagrantemente inconstitucional face ao Estado de Direito. Note-se que, no exemplo ora observado, a soberania não foi representada pelo que estava na lei, mas pela decisão não adstrita à lei do STJ.

O outro caso que merece destaque na análise aqui proposta diz respeito à liberação da extração do gás de xisto na bacia do Rio Paraná. Da situação resultou um cenário em que a ordem constitucional é subvertida - ainda que com argumentos constitucionais - para, ao sabor de argumentos de emergência, promover o "desenvolvimento econômico" (sic) da indústria nacional ${ }^{5}$.

${ }^{5}$ Decisão disponível em:

http://www.jfpr.jus.br/consulta/acompanhamento/resultado pesquisa popup.php?txtPalavraGera da=mcvq\&hdnRefld=cf33f51e67bca9409e1e693e1ab7e4bf\&selForma=NU\&txtValor=50055098.2014.404.7005\&chkMostrarBaixados=\&todasfases $=$ \&todosvalores $=\&$ todaspartes $=\&$ txtDataFase $=0$

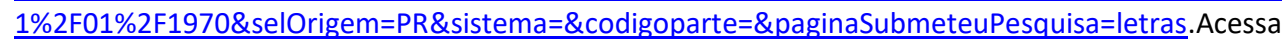
do em dezembro de 2015 .

Revista Publicum

Rio de Janeiro, Número 2, 2016, p. 181-202.

http://www.e-publicacoes.uerj.br/index.php/publicum

DOI: 10.12957/publicum.2016.22849 
Em 2013, a Agência Nacional do Petróleo (ANP), sob pressão do Ministério das Minas e Energia e de empresas estrangeiras, exploradoras de recursos minerais, autorizou a extração do gás de xisto na bacia do Rio Paraná, que compreende parte do Aquífero Guarani, patrimônio de extensão transnacional e transgeracional. Ocorre, entretanto, conforme anunciado na Ação Civil Pública no 5005509-18.2014.404.7005/PR, manejada pelo Ministério Público Federal, que a ANP inverteu a ordem do processo licitatório e, com isso, ignorou pontos de extrema relevância, dentre os quais a análise de estudos apresentados por outros órgãos governamentais, coordenados pelo IBAMA, que demonstravam que a referida extração implicaria danos irreversíveis para o patrimônio público (meio ambiente) - leia-se, aqui, para o Aquífero Guarani.

Embora as atividades tenham sido suspensas desde o início, por força de decisão liminar concedida no TRF da 4ạ Região, algumas questões se sobrelevam neste caso. A primeira delas diz respeito à atuação do própria Administração Pública. É regra que o planejamento de qualquer governo tem que estar de acordo com as diretrizes constitucionais. Neste caso, o planejamento de exploração do gás de xisto necessariamente deveria estar intimamente vinculado às diretrizes da Constituição Econômica. Neste passo, é de lembrar que "desenvolvimento", previsto na CRFB, não pode ser confundido com "crescimento" ou com mera "modernização".

Sobre o assunto, Eros R. Grau (1981) observa que o crescimento é apenas uma pequena parte do desenvolvimento, de modo que este importa num processo de mobilidade social que deve levar a um salto de uma estrutura social para a outra, acompanhado do nível econômico e do nível cultural-intelectual. Não se pode querer identificar que os efeitos devastadores de extração do gás de xisto na bacia do Rio Paraná, para o exclusivo interesse de parte da indústria brasileira, possam atender os pressupostos de desenvolvimento impressos na Constituição quando coloca em xeque, justamente, uma autossustentabilidade para as gerções futuras.

Outro ponto que se sobreleva do caso está relacionado à própria decisão do TRF-4. Embora tenha deferido os pedidos insertos na ação manejada pelo MPF, a decisão chama a atenção pelo modo como resolveu o problema. Explica-se. Para resolver a questão posta na ação (desenvolvimento econômico regional vs. proteção ao meio ambiente), o juiz responsável pelo processo lançou mão da técnica da ponderação, entendendo haver um genuíno conflito de princípios, conforme expôs.

Importa destacar, entretanto, que o caso não compreendia "conflito de princípios". De acordo com o relatório da decisão e os dispositivos legais que a fundamentam, a 
problemática lá exposta dá conhecimento de que a ANP flagrantemente violou as diretrizes legais que era "obrigada" a observar. Isto é, regras infraconstitucionais devidamente previstas em lei e que, em última análise, tem sua razão de existir para fins de proteção de outros núcleos de direitos fundamentais. Tais leis disciplinam todo o processo administrativo para a autorização de atos que impliquem prejuízo ao meio ambiente, como, por exemplo, a exploração do gás de xisto.

A simples verificação de que o processo licitatório foi maculado pela desconsideração de estudos e inversão de ordem, com prejuízos inclusive no âmbito democrático, deixa claro que, longe de um conflito de princípios, o que se têm é, num primeiro momento, ofensa reflexa à Constituição. Circunstância que, portanto, não deixa espaço para a consideração de um "desenvolvimento econômico regional". Isto é, não se pode falar de desenvolvimento econômico regional, conquanto que as condições para alcançá-lo não foram observadas. No caso, a violação dos preceitos constitucionais e infraconstitucionais correlatos é suficiente para atacar e anular a atuação da ANP, sem que se recorra à técnica da ponderação. Em verdade, o caso, em vista do descumprimento de regras, reclama pela técnica da subsunção. Aqui, a técnica do tudo ou nada tem lugar.

Pensar que há um conflito de princípios, nesta hipótese, é, por outro lado, reconhecer que a atuação da ANP, mesmo com as irregularidades que a acompanhou, materializou um "direito" com força normativa, que, para ser restringido, exigiria ponderação. E, ao ser ponderado, deixaria margem para que fosse validado em outras instâncias. Com efeito, tal atuação, bem da realidade, representou um quadro de inconstitucionalidade institucional e normativa. A par disso, a resolução judicial abordou o tema como se do "ser" pudesse vir o "dever-ser".

A análise em questão não requer maior aprofundamento técnico para se diagnosticar que a soberania, nos dois casos citados, foi suprimida em duas instâncias, administrativa e judiciária. Nos duas situações, a lei, que deveria ter sido observada, foi flagrantemente ignorada. É a decisão do STJ quando suspende a lei e suprime um direito garantido por força constitucional ou, ainda, a decisão da Administração Pública, quando negligencia as diretrizes constitucionais para promover o desenvolvimento econômico da indústria nacional. Tudo isso, ao sabor de conveniências políticas vistas como reais ou de exceção.

Ao endereçar uma determinada realidade, a ideia de decisão nos casos analisados parece se liberar de toda sua obrigação formativa (e normativa) constitucional, superando - e muito - qualquer limite de jurisdição. A decisão, seja ela judicial ou extrajudicial, é moldada para a manutenção de determinadas estruturas, nas quais excetua-se a regra da Constituição para transformar a exceção em normalidade. 
Neste quadro, por um lado, estão em jogo o controle do poder do povo e o fato de que, até hoje, a soberania não foi encontrada. Referido quadro relega a segundo plano, por conseguinte, a ideia de cidadania. Em nenhuma esfera a soberania encontra seu lugar de fala. A lei, sua legítima representante, é uma entidade amorfa e esquecida, de modo que o que se decide, decide-se em espaços em que a cidadania é ignorada, onde o povo é a instituição a ser governada, e não representada.

O paradigma político do Estado, na atualidade, define-se pela dissociação entre a ordem normativa (oficial) e a ordem real de poderes, e de modo que, à semelhança de Weimar, a soberania invoca uma nova identificação. A lógica do Estado moderno segue a lógica da economia global contemporânea, a qual é estruturada em torno de redes e fluxos financeiros. Tudo se decide neste contorno e, cada vez mais, em esferas em que a participação cidadã não encontra abrigo. Enquanto isso, o Judiciário é chamado para fazer as vezes de decisões afetas à soberania e ao exercício da cidadania.

A questão de quem é o soberano volta com toda sua força para o centro da argumentação. Não é possível afirmar que, na ordem real de poderes, o titular da soberania seja, na clássica noção republicana, o povo. O princípio de que toda a soberania reside essencialmente no povo cede espaço para a identificação de que o poder que emana do povo é, na realidade, um poder meramente simbólico, realizado, no mais das vezes, no poder mais periférico.

As decisões que são tomadas são tomadas como que em um Estado de Exceção, à revelia da lei - voz última dos cidadãos que detém a soberania - por grandes organizações financeiras internacionais ${ }^{6}$. Parafraseando Saramago, pode-se afirmar que a soberania está aí, como uma espécie de santa no altar e de quem já não se esperam milagres, mas está aí como uma referência, a "soberania". É uma soberania sequestrada, condicionada e amputada.

\footnotetext{
${ }^{6}$ Aqui, é oportuno o entendimento de Giorgio Agamben. Para o autor (2004, p. 24), no Estado de Exceção "o que realmente está em jogo é o problema de significado jurídico de uma esfera de ação em si extrajurídica". Agamben (2004) observa que o totalitarismo moderno pode ser definido como a instauração, por meio do Estado de Exceção, de uma guerra civil legal, que permitiria a eliminação física não só dos adversários políticos, mas também de categorias inteiras de cidadãos que, por qualquer razão, pareçam não integráveis ao sistema político. Desde então, a criação voluntária de um "estado de emergência" permanente (ainda que, eventualmente, não declarado no sentido técnico) teria se tornado uma das práticas essenciais dos Estados contemporâneos, inclusive dos chamados democráticos. Agamben (2004) salienta que diante do incessante avanço do que foi definido como uma "guerra civil mundial", o Estado de Exceção tende cada vez mais a se apresentar como paradigma de governo dominante na política contemporânea. Esse deslocamento de uma medida provisória e excepcional para uma técnica de governo ameaçaria, na visão do autor, transformar radicalmente a estrutura e o sentido da distinção tradicional entre os diversos tipos de Constituição. Para Agamben (2004), o Estado de Exceção seria um patamar de indeterminação entre democracia e absolutismo.
}

Revista Publicum

Rio de Janeiro, Número 2, 2016, p. 181-202.

http://www.e-publicacoes.uerj.br/index.php/publicum DOI: 10.12957/publicum.2016.22849 
Os exemplos são muitos e demonstram com certo grau de certeza que a soberania é direito a ser (re)afirmado em espaços coletivos, os quais, a todo modo, parecem não existir. No entanto, no campo do direito, a questão de quem é o Guardião da Constituição precisa ser seriamente respondida. Fábio Konder Comparato (1985) sugere que, embora desvalorizado pelo uso promíscuo e inepto, o conceito de soberania ainda é importante na construção e na compreensão de qualquer regime político, haja vista que toda a organização estatal se reduz, afinal, a uma regulação hierárquica de poderes, formando um sistema. Isto é, um conjunto ordenado estruturalmente em vista de determinada finalidade.

No entanto, observa o autor (COMPARATO, 1985), é possível - e mesmo frequente - que o esquema normativo do sistema, expresso no texto constitucional, não corresponda à realidade efetiva do poder na sociedade. Quando isso ocorre, a dissociação entre a ordem oficial e a ordem real de poderes abre-se para a identificação da soberania ou do poder supremo. Considerando que atribuição da soberania tem sido, ao longo da história, a consagração jurídica de uma supremacia de poder já atuante na realidade social, a pergunta que se faz agora é: qual poder queremos juridicamente consagrar, o da toga ou do povo?

\section{Referências bibliográficas}

AGAMBEN, Giorgio. O que é um dispositivo? Outra travessia, Florianópolis, n. 5, p. 9-16, jan. 2005.2 Disponível em: <https://periodicos.ufsc.br/index.php/Outra/article/view/12576/11743>. Acessado em 11 de dezembro de 2015: http://dx.doi.org/10.5007/12576.

2002.

. Homo Sacer: o poder soberano e a vida nua I. Belo Horizonte: Editora UFMG,

. Estado de Exceção. São Paulo: Editora Boitempo, 2004.

BENVINDO, Juliano Zaiden e Costa, Alexandre. A Quem Interessa o Controle Concentrado De Constitucionalidade? - O Descompasso entre Teoria e Prática na Defesa dos Direitos Fundamentais (Who is Interested in the Centralized System of Judicial Review? - The Mismatch between Theory and Practice in the Protection of Basic Rights). 2014. Disponível em: $\quad$ <http://ssrn.com/abstract=2509541orhttp://dx.doi.org/10.2139/ssrn.2509541>. Acessado em dez. de 2015.

BERCOVICI. Soberania e Constituição: Para uma crítica do constitucionalismo. São Paulo: Quartier Latin, 2008

Entre o estado total e o estado social: atualidade do debate sobre direito, estado e economia na República de Weimar., 2003. Tese USP, disponível em: <http://www.teses.usp.br/teses/disponiveis/livredocencia/2/tde-22092009150501/fr.php>. Acessado em fevereiro de 2015. 
. Carl Schmitt, o Estado Total e o Guardião da Constituição. Revista Brasileira de Direito Constitucional. Vol. 1. São Paulo, 2003.

. Constituição e Política: uma relação difícil. Revista Lua Nova, n.o 61. disponível em: <http://www.scielo.br/pdf/In/n61/a02n61.pdf>. Acessado em fevereiro de 2015.

BOBBIO, Norberto. O Futuro da Democracia. Rio de Janeiro: Editora Paz e Terra, 1986.

BODIN, Jean. Les six livres de la République. 10. ed., Bordeaux: Éditions Confluences, 1999.

COMPARATO, Fábio Konder. Por que não a soberania dos pobres? in: SADER, Emir (org). Constituinte e democracia no Brasil hoje. São Paulo: Brasiliense, 1985, pp. 85-109.

HESPANHA, Antônimo Manuel. Cultura jurídica europeia: síntese de um milênio. Florianópolis: Fundação Boiteux, 2005.

JELLINEK, Georg. Teoría General del Estado. México: Fondo de Cultura Económica. 2000.

KANT, Immanuel. A Metafísica dos Costumes. Bauru (SP): Editora Edipro, 2008.

KELSEN, Hans. Teoria Pura do direito. São Paulo: Martins Fontes, 2003.

. Jurisdição Constitucional. São Paulo: Martins Fontes, 2003b.

. A democracia. Tradução de Ivone Castilho Benedetti, Jefferson Luiz Camargo, Marcelo Brandão Cipolla e Vera Barkow. São Paulo: Martins Fontes, 2000.

SÁ, Alexandre Franco de. Introdução ao Pensamento Político de Carl Schmitt. Revista Filosófica de Coimbra, v. 13, n. 26, 2004, pp. 411-421.

Decisionismo e ficção no pensamento de Carl Schmitt. Revista Brasileira de Estudos Políticos. Belo Horizonte: 2012. N.o 105. pp. 21-46.

. Teologia Política. Artigo para o Dicionário de Filosofia Moral e Política - Instituto de Filosofia da Linguagem da Universidade Nova de Lisboa.

SCHMITT, Carl. Teologia política I. Quatro capítulos sobre a doutrina da soberania (1922). Belo Horizonte: Del Rey, 2006

. O guardião da Constituição. Belo Horizonte: Del Rey, 2007

SEELAENDER, Airton L. C. L. Notas sobre a constituição do direito público na idade moderna: a doutrina das leis fundamentais. Revista Sequência, no 198, V. 53, p. 197-232, dez. 2006 